J Am Chem Soc. 2016 April 27; 138(16): 5234-5237. doi:10.1021/jacs.6b02153.

\title{
Enantioselective $\gamma$-Alkylation of $\alpha, \beta$-Unsaturated Malonates and Ketoesters by a Sequential Ir-Catalyzed Asymmetric Allylic Alkylation/Cope Rearrangement
}

\author{
Wen-Bo Liu ${ }^{\dagger}$, Noriko Okamoto ${ }^{\dagger}$, Eric J. Alexy, Allen Y. Hong, Kristy Tran, and Brian M. \\ Stoltz \\ Warren and Katharine Schlinger Laboratory for Chemistry and Chemical Engineering, Division of \\ Chemistry and Chemical Engineering, California Institute of Technology, Pasadena, California \\ 91125
}

\begin{abstract}
A catalytic, enantioselective $\gamma$-alkylation of $\alpha, \beta$-unsaturated malonates and ketoesters is reported. This strategy entails a highly regio- and enantioselective iridium-catalyzed a-alkylation of an extended enolate, and a subsequent translocation of chirality to the $\gamma$-position via a Cope rearrangement.
\end{abstract}

\section{Graphical abstract}

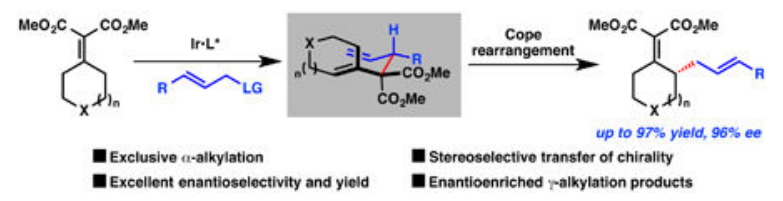

\begin{abstract}
Enantioenriched unsaturated carbonyl compounds are valuable synthetic intermediates owing to their multiple reactive sites poised for further manipulation to synthesize complex molecules with contiguous stereocenters. ${ }^{1}$ Direct asymmetric functionalization at the $\gamma$ position of $a, \beta$-unsaturated carbonyl derivatives would be a straightforward way to access such motifs. However, this transformation has proven challenging, likely due to the absence of proximal functionality to interact with a catalyst in order to induce facial selectivity.

Furthermore, issues arise with regard to regioselectivity ( $a$ - versus $\gamma$-functionalization) and chemoselectivity ( $\mathrm{C}$ vs O-alkylation). To date, this transformation has only been achieved in a handful of examples. ${ }^{2,3}$ In particular, work from the Tunge group demonstrated the ability of a, $\beta$-unsaturated carbonyls to undergo palladium-catalyzed decarboxylative allylation/ Cope rearrangement, but only one asymmetric example with alkylidene malononitriles was provided with poor enantiocontrol. ${ }^{2 b}$ Recently, the Jørgensen group reported an asymmetric $\gamma$-allylation of $a, \beta$-unsaturated aldehydes via organocatalysis combined with either iridium
\end{abstract}

Correspondence to: Brian M. Stoltz.

$\dagger$ Author Contributions: These authors contributed equally to this work.

Supporting Information: Experimental procedures, characterization data, single crystal X-ray analysis. This material is available free of charge via the Internet at http://pubs.acs.org. 
or palladium catalysis, providing branched or linear products respectively. ${ }^{3 \mathrm{~g}}$ Alternatively, a Birch-Cope sequence has been developed by the Malachowski group as an efficient method to access $\gamma$-alkylated $\alpha, \beta$-unsaturated ketoesters, although stoichiometric alkali metals and chiral auxiliaries were required. ${ }^{4}$ Despite these reports, a general strategy to selectively produce $\gamma$-functionalized unsaturated carbonyl derivatives has remained elusive.

Since the initial report in 1997, iridium-catalyzed allylic alkylation has emerged as a successful strategy for the assembly of chiral chemical architectures. ${ }^{5,6}$ Numerous studies have been performed in this field elucidating a wide range of suitable nucleophiles. ${ }^{5,7}$ However, the use of $a, \beta$-unsaturated carbonyls as nucleophiles has seen little attention. We hypothesized that $\alpha$-alkylation of an extended enolate derived from such compounds could provide chiral 1,5-dienes poised to undergo a [3,3]-sigmatropic rearrangement, producing $\gamma$ -alkylation products (Scheme 1). ${ }^{8}$ A similar approach was utilized by Arseniyadis and Cossy to produce $\gamma$-substituted $2(5 \mathrm{H})$-furanones. ${ }^{9}$

We began our studies with the seven-membered cyclic alkylidene malonate 1a and cinnamyl carbonate $\mathbf{2 a}$ as the model substrates (Table 1 ). A variety of conditions including different bases, solvents, and substrate ratios were examined with iridacycle catalysts ${ }^{10}$ generated in situ by the treatment of $\left[\operatorname{Ir}(\operatorname{cod}) \mathrm{Cl}_{2}\right.$ and phosphoramidites (Figure 1) with 1,5,7triazabicyclo[4.4.0]dec-5-ene (TBD). ${ }^{11,12}$ Using $N$-aryl phosphoramidite ligand L1, developed by the You group, ${ }^{12,13} \mathbf{a}$-alkylation product 3aa is furnished in perfect enantioselectivity and moderate regioselectivity (entry 1). The investigation of solvents revealed that THF affords optimal reactivity and selectivity (See SI for details). The use of Feringa-type ligands ${ }^{14} \mathbf{L} \mathbf{2}$ and $\mathbf{L 3}$ resulted in either a lack of reactivity or formation of a complex mixture of side products (entries 2 and 3). Moreover, ligands $\mathbf{L 4}$ and $\mathbf{L} 5$ led to diminished regio-and enantioselectivity, respectively (entries 4 and 5). The use of the more sterically congested $3,3^{\prime}$-diphenyl-substituted phosphoramidite $\mathbf{L 6}^{15}$ resulted in a dramatic improvement in regioselectivity, and a modest improvement in yield (entry 6). After a careful analysis of the crude reaction mixture, we found that the moderate yield is due to hydrolysis of the carbonate under the reaction conditions. Thus, by increasing the quantity of the carbonate (1.5-2 equiv) and switching the base $(\mathrm{LiO} t-\mathrm{Bu})$, we were able to obtain the desired product 3aa in 93\% yield, $>99 \%$ ee, and $>20: 1$ regioselectivity (entries 8 and 9 ). The absolute configuration of a-alkylated product $(R)$-3aa was determined by X-ray crystallography. ${ }^{16}$

With optimized conditions for the a-alkylation procedure established, we next examined the possibility of intramolecular chirality transfer by a Cope rearrangement. To our delight, 1,5diene 3aa was converted to the rearranged $\gamma$-alkylated product $\mathbf{5 a a}{ }^{17}$ in $98 \%$ yield and $95 \%$ ee after heating in toluene (Scheme 2 ). The high degree of chirality transfer $(96 \%)^{18}$ can be rationalized by the preferential rearrangement of the diene 3aa through a chair-like transition state (TS1), over the corresponding boat-like transition state (TS2). A one-pot procedure for the allylic alkylation/Cope rearrangement is also possible, providing the product 5aa in $91 \%$ overall yield and $96 \%$ ee (Scheme 3).

We next explored the impact of functional groups and ring size on this sequential protocol (Scheme 3). ${ }^{19}$ A variety of cinnamyl carbonates containing either electron-rich or electron- 
deficient substituents are well tolerated and the corresponding $\gamma$-alkylation products (5ab5af) were obtained in high yield and excellent enantioselectivity. Moreover, a thienylsubstituted allylic carbonate is also compatible in this reaction, delivering product $\mathbf{5 a g}$ in good yield and enantioselectivity. Five-and six-membered unsaturated malonates provide the desired products (5ca and 5ba), albeit in slightly decreased yield (75\% and 83\%) and enantioselectivity (90\% ee and $91 \%$ ee), respectively. Notably, oxygen, sulfur, and nitrogen containing heterocycles were compatible, providing the corresponding products (5da-5fa) in excellent ee and yield, except for 5ea which was obtained in moderate yield.

Concurrent with these studies, we investigated the reactivity of a endocyclic $\alpha, \beta$-unsaturated $\beta$-ketoesters, a more challenging class of nucleophiles. It is widely appreciated that iridiumcatalyzed allylic alkylation of prochiral nucleophiles can be problematic due to a lack of diastereocontrol during the formation of vicinal stereocenters. ${ }^{5}$ Until recently, success has been limited to only a few examples. ${ }^{13,20,21}$ Subjecting a, $\beta$-unsaturated $\beta$-ketoester $\mathbf{6 a}$ to a slightly modified version of our optimized conditions, the branched product 7aa was formed exclusively, but as a 1:1 mixture of diastereomers (entry 1, Table 2). When ligand $\mathbf{L} \mathbf{1}$ was used, a slight increase in diastereo- and enantioselectivity was obtained (entry 2). Lowering the reaction temperature gave modest improvement in diastereoselectivity, however the reaction required days to reach a satisfactory conversion (entry 3 ).

Unfortunately, despite extensive attempts to further enhance the diastereoselectivity, no improved conditions were identified. We therefore decided to move forward with this moderate diastereoselectivity and evaluate the substrate scope of the reaction with regard to both reaction partners (Scheme 4). It is worth noting that in each case, both diastereomers were isolated and characterized (see SI for details). The reaction with an eight-membered unsaturated $\beta$-ketoester gave desired product $\mathbf{7 b a}$ with high branched selectivity and moderate diastereoselectivity. Six-membered substrate afforded the corresponding alkylation product $7 \mathbf{c a}^{22}$ with an increased diastereo- and regioselectivity, but in only moderate yield due to the decomposition of the $\beta$-ketoester during the reaction. Lactam derivative 7da was also accessed, although with diminished enantioselectivities for both diastereomers. Finally, several carbonates bearing various electronically differentiated substituents were found to be well tolerated, and the corresponding products 7ad-7af were furnished in good yield, with high enantioselectivity and moderate diastereoselectivity.

Having investigated the allylic alkylation, we next turned to the Cope rearrangement (Scheme 5). The major isomer (7aa) undergoes the rearrangement more readily than the minor isomer 7aa'. Again, this is likely due to geometrical differences of a chair-like transition state of the major isomer (TSI) in contrast to a boat-like transition state of the minor isomer (TSII). The rigidity of the transition state plays a key role in enabling the chirality transfer $(>99 \%){ }^{4 \mathrm{~b}}$ It is worth noting that the rearranged $\gamma$-alkylation products from the major isomer 7aa and the minor isomer 7aa'; have opposite absolute configurations (Scheme 5a and 5b). Since the diastereomers 7aa and 7aa' have identical tertiary chiral centers, the outcome of the rearrangement is controlled solely by the quaternary center.

In summary, we have developed a sequential iridium-catalyzed allylic alkylation/Cope rearrangement to synthesize enantioenriched $\gamma$-substituted $\alpha, \beta$-unsaturated malonates and 
$\beta$-ketoesters. The initial alkylation reaction provides efficient access to chiral 1,5-dienes with high regio- and enantioselectivities, with $N$-aryl phosphoramidite ligands being crucial. Selective translocation of the newly established chirality to the $\gamma$-position was realized by a subsequent thermal Cope rearrangement. Further studies toward the application of this useful method in natural product synthesis are currently ongoing in our laboratory.

\section{Supplementary Material}

Refer to Web version on PubMed Central for supplementary material.

\section{Acknowledgments}

We thank NIH-NIGMS (R01GM080269), the Gordon and Betty Moore Foundation, and Caltech for financial support. Shanghai Institute of Organic Chemistry (SIOC) is thanked for a postdoctoral fellowship to W.-B. L. Hiroshima International University is thanked for a postdoctoral fellowship to N.O. EJ.A. is grateful to the National Science Foundation for a predoctoral fellowship. K.T. acknowledges support from California HIV/AIDS Research Program (F08-CT-201). Mr. Lawrence Henling and Dr. Michael Takase are acknowledged for X-ray analyses. We thank Dr. David VanderVelde for NMR expertise, and Dr. Mona Shahgholi and Naseem Torian for mass spectrometry assistance. The authors are also thankful to Professor Shu-Li You for the generous donation of $N$-aryl ligands and for helpful discussions.

\section{References}

1. Seletecd examples: Schreiber SL, Santini C. J Am Chem Soc. 1984; 106:4038.Nakamura H, Ye B, Murai A. Tetrahedron Lett. 1992; 33:8113.Biber N, Möws K, Plietker B. Nature Chemistry. 2011; 3:938.Harvey NL, Krysiak J, Chamni S, Cho SW, Sieber SA, Romo D. Chem Eur J. 2015; 21:1425. [PubMed: 25488266]

2. (a) Sugiura M, Yagi Y, Wei SY, Nakai T. Tetrahedron Lett. 1998; 39:4351.(b) Waetzig SR, Rayabarapu DK, Weaver JD, Tunge JA. Angew Chem Int Ed. 2006; 45:4977.(c) Hyde AM, Buchwald SL. Angew Chem Int Ed. 2008; 47:177.(d) Liu X, Chen X, Mohr JT. Org Lett. 2015; 17:3572. [PubMed: 26132556]

3. (a) Bertelsen S, Marigo M, Brandes S, Dinér P, Jørgensen KA. J Am Chem Soc. 2006; 128:12973. [PubMed: 17002394] (b) Smith SW, Fu GC. J Am Chem Soc. 2009; 131:14231. [PubMed: 19772285] (c) Stiller J, Marqués-López E, Herrera RP, Fröhlich R, Strohmann C, Christmann M. Org Lett. 2010; 13:70. [PubMed: 21138316] (d) Bergonzini G, Vera S, Melchiorre P. Angew Chem Int Ed. 2010; 49:9685.(e) Ikeda M, Miyake Y, Nishibayashi Y. Organometallics. 2012; 31:3810.(f) Xu J, Jin Z, Chi YR. Org Lett. 2013; 15:5028. [PubMed: 24067098] (g) Næsborg L, Halskov KS, Tur F, Mønsted SMN, Jørgensen KA. Angew Chem Int Ed. 2015; 54:10193.(h) Xiao W, Yin X, Zhou Z, Du W, Chen YC. Org Lett. 2016; 18:116. [PubMed: 26653774]

4. (a) Paul T, Malachowski WP, Lee J. Org Lett. 2006; 8:4007-4010. [PubMed: 16928060] (b) Paul T, Malachowski WP, Lee J. J Org Chem. 2007; 72:930. [PubMed: 17253813] (c) Qiao Y, Kumar S, Malachowski WP. Tetrahedron Lett. 2010; 51:2636.

5. For recent reviews, see: Helmchen G, Dahnz A, Dübon P, Schelwies M, Weihofen R. Chem Commun. 2007:675.Hartwig JF, Pouy MJ. Top Organomet Chem. 2011; 34:169.Tosatti P, Nelson A, Marsden SP. Org Biomol Chem. 2012; 10:3147. [PubMed: 22407450] Liu WB, Xia JB, You SL. Top Organomet Chem. 2012; 38:155.

6. (a) Takeuchi R, Kashio M. Angew Chem Int Ed. 1997; 36:263.(b) Janssen JP, Helmchen G. Tetrahedron Lett. 1997; 38:8025.(c) Ohmura T, Hartwig JF. J Am Chem Soc. 2002; 124:15164. [PubMed: 12487578]

7. Selected examples: Lipowsky G, Miller N, Helmchen G. Angew Chem Int Ed. 2004; 43:4595.Alexakis A, Polet D. Org Lett. 2004; 6:3529. [PubMed: 15387540] Graening T, Hartwig JF. J Am Chem Soc. 2005; 127:17192. [PubMed: 16332060] He H, Zheng XJ, Li Y, Dai LX, You SL. Org Lett. 2007; 9:4339. [PubMed: 17854201] Spiess S, Welter C, Franck G, Taquet JP, Helmchen G. Angew Chem Int Ed. 2008; 47:7652.Liu WB, He H, Dai LX, You SL. Org Lett. 2008; 10:1815. [PubMed: 18386906] Hamilton JY, Sarlah D, Carreira EM. J Am Chem Soc. 2013; 
135:994. [PubMed: 23256708] Chen M, Hartwig JF. Angew Chem Int Ed. 2014; 53:12172.Chen M, Hartwig JF. J Am Chem Soc. 2015; 137:13972. and references therein. [PubMed: 26441002]

8. Ir-catalyzed allylic alkylation of azlactones followed by aza-Cope rearrangement was reported previously. However, chiral allylic acetates were required, and the selectivity was poor, see: Kawatsura M, Tsuji H, Uchida K, Itoh T. Tetrahedron. 2011; 67:7686.

9. Fournier J, Lozano O, Menozzi C, Arseniyadis S, Cossy J. Angew Chem Int Ed. 2013; 52:1257.

10. (a) Hartwig JF, Stanley LM. Acc Chem Res. 2010; 43:1461. [PubMed: 20873839] (b) Spiess S, Raskatov JA, Gnamm C, Brödner K, Helmchen G. Chem Eur J. 2009; 15:11087. [PubMed: 19750530]

11. Welter C, Koch O, Lipowsky G, Helmchen G. Chem Commun. 2004:896.

12. (a) Liu WB, He H, Dai LX, You SL. Synthesis. 2009:2076.(b) Liu WB, Zheng C, Zhuo CX, Dai LX, You SL. J Am Chem Soc. 2012; 134:4812. [PubMed: 22309279]

13. (a) Wu QF, He H, Liu WB, You SL. J Am Chem Soc. 2010; 132:11418. [PubMed: 20677752] (b) Zhuo CX, Liu WB, Wu QF, You SL. Chem Sci. 2012; 3:205.(c) Yang ZP, Wu QF, You SL. Angew Chem Int Ed. 2014; 53:6986.(d) Yang ZP, Wu QF, Shao W, You SL. J Am Chem Soc. 2015; 137:15899. [PubMed: 26605697]

14. Teichert JF, Feringa BL. Angew Chem Int Ed. 2010; 49:2486.

15. Cheng Q, Wang Y, You SL. Angew Chem Int Ed. 2016; 55:3496-3499.

16. See Supporting Information for details.

17. The absolute structure of $\mathbf{5} \mathbf{a a}$ was assigned by X-ray analysis of its derivative, see Supporting Information for details.

18. Chirality transfer $=\left(e_{\text {product }} / \mathrm{e}_{\text {substrate }}\right) \times 100 \%$.

19. Certain $\gamma$-alkylation products and starting materials were inseparable, thus a two-step procedure was required, see $\mathrm{SI}$.

20. (a) Liu WB, Reeves CM, Virgil SC, Stoltz BM. J Am Chem Soc. 2013; 135:10626. [PubMed: 23829704] (b) Liu WB, Reeves CM, Stoltz BM. J Am Chem Soc. 2013; 135:17298. [PubMed: 24160327] (c) Zhang X, Liu WB, Tu HF, You SL. Chem Sci. 2015; 6:4525.

21. (a) Kanayama T, Yoshida K, Miyabe H, Takemoto Y. Angew Chem Int Ed. 2003; 42:2054.(b) Chen W, Hartwig JF. J Am Chem Soc. 2013; 135:2068. [PubMed: 23286279] (c) Krautwald S, Sarlah D, Schafroth MA, Carreira EM. Science. 2013; 340:1065. [PubMed: 23723229] (d) Chen W, Chen M, Hartwig JF. J Am Chem Soc. 2014; 136:15825. [PubMed: 25337972]

22. See SI for the assignment of the absolute structure of 7ca. 
<smiles>C[C@H]1CCc2ccccc2N1p1oc2ccc3ccccc3c2c2c(ccc3ccccc32)o1</smiles>

$\left(S, S_{a}\right)-L 1$<smiles>c1ccc2c(c1)CCCN2p1oc2ccc3ccccc3c2c2c(ccc3ccccc32)o1</smiles>

(士)-L4<smiles>C[C@H](c1ccccc1)N(C(c1ccccc1)c1ccccc1)p1oc2ccc3ccccc3c2c2c(ccc3ccccc32)o1</smiles>

$\left(S, S, S_{a}\right)-L 2$<smiles>CC1CCc2ccccc2N1p1oc2ccc3ccccc3c2c2c(ccc3ccccc32)o1</smiles>

$\left(R, S_{a}\right)-L 5$<smiles>CC(=O)OCCCCCCC(C)C</smiles>
$\left(R, R, R_{a}\right)-L 3$<smiles>C[C@@H]1CCc2ccccc2N1P1Oc2c(-c3ccccc3)cc3ccccc3c2-c2c(-c3ccccc3)cc3ccccc3c21</smiles>

$\left(S, S_{a}\right)-L 6$

Figure 1.

Representative phosphoramidite ligands. 


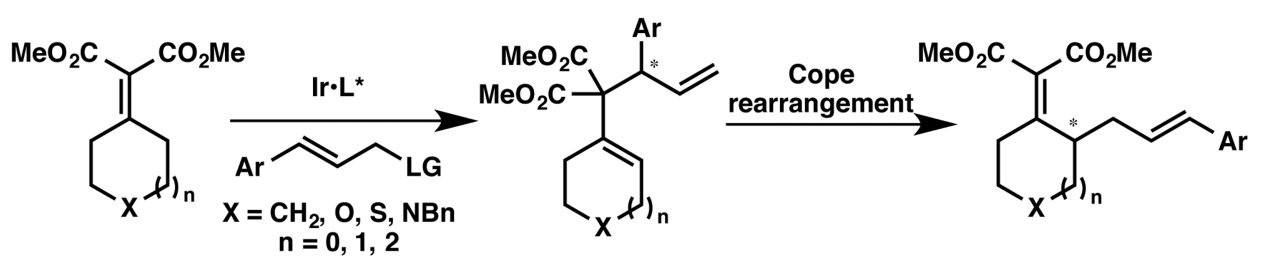

Scheme 1. Sequential Asymmetic Allylic Alkylation/Cope Rearrangement 


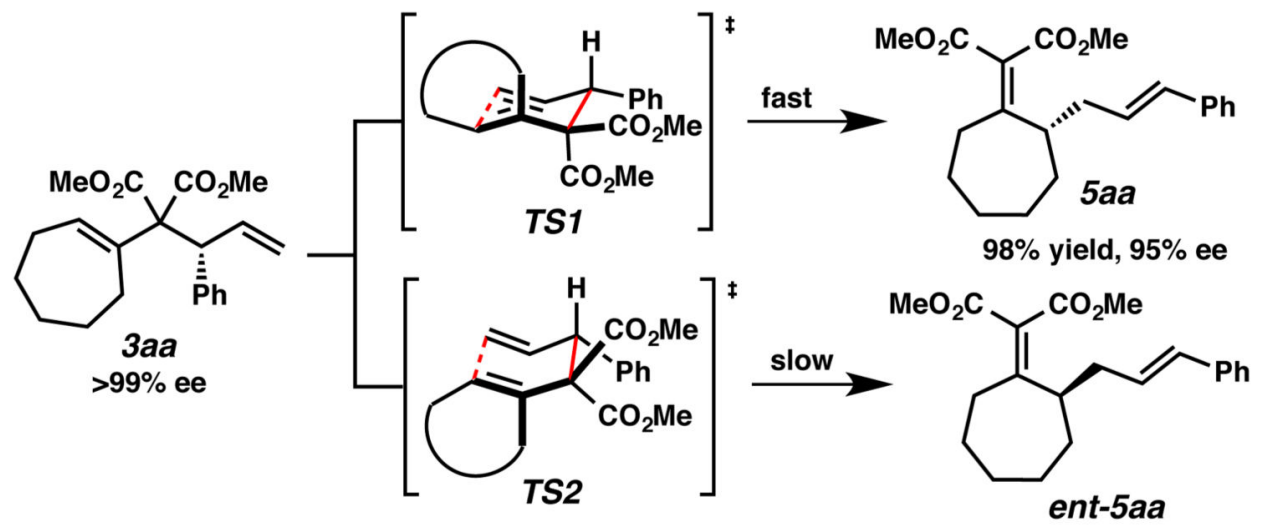

Scheme 2. Cope Rearrangement of 3aa. ${ }^{a}$

${ }^{a}$ Reaction conditions: $0.1 \mathrm{mmol}$ of $\mathbf{3 a a}$ in toluene at $100{ }^{\circ} \mathrm{C}$ for $5 \mathrm{~h}$. 


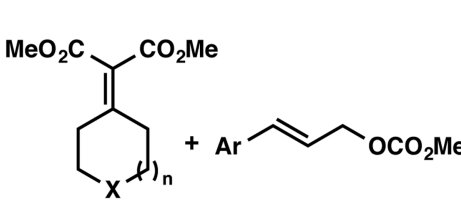

1) $[\operatorname{lr}(\operatorname{cod}) \mathrm{Cl}]_{2}(2 \mathrm{~mol} \%)$ L6 (4 mol \%) TBD (10 $\mathrm{mol} \%)$ LiOt-Bu (1.2 equiv) THF, $20^{\circ} \mathrm{C}, 12-16 \mathrm{~h}$

2) toluene, $100{ }^{\circ} \mathrm{C}, 5 \mathrm{~h}$

1

2

$\mathrm{X}=\mathrm{CH}_{2}, \mathrm{O}, \mathrm{S}, \mathrm{NBn} ; \mathrm{n}=\mathbf{0 , 1}, 2$<smiles>[X][M][C@H]1CCCC(=C(C(C)=O)C(C)=O)[C@H]1CC=CBr</smiles>

5<smiles>COC(=O)C(C(C)=O)=C1CCCCCC1CC=Cc1ccccc1</smiles>

$5 \mathrm{aa}^{d}$

$91 \%$ yield, $96 \%$ ee

$\mathrm{MeO}_{2} \mathrm{C} \mathrm{CO}_{2} \mathrm{Me}$<smiles>C=CC[C@H]1CCCCCC1=C(C(C)=O)C(C)=O</smiles>

$5 a b$

$79 \%$ yield, $96 \%$ ee

$\mathrm{MeO}_{2} \mathrm{C} Y \mathrm{CO}_{2} \mathrm{Me}$<smiles>COC(=O)C(C(C)=O)=C1CCCCC[C@H]1CC=Cc1cccc(OC)c1</smiles>

$90 \%$ yield, $97 \%$ ee

$\mathrm{MeO}_{2} \mathrm{C} \rightleftharpoons \mathrm{CO}_{2} \mathrm{Me}$<smiles>CC(=O)C(C)=C1CCCCC[C@H]1CC=Cc1cccc(Cl)c1</smiles>

$97 \%$ yield, $96 \%$ ee<smiles>CC(=O)C(C(C)=O)=C1CCCCC[C@H]1CC=Cc1cccs1</smiles>

$\mathrm{MeO}_{2} \mathrm{C} \mathrm{CO}_{2} \mathrm{Me}$<smiles>CC(C)=C1CCCC[C@H]1CC=Cc1ccccc1</smiles>

$83 \%$ yield, $91 \%$ ee<smiles>COC(=O)C(C(C)=O)=C1CCOC[C@H]1CC=Cc1ccccc1</smiles>

$91 \%$ yield, $94 \%$ ee<smiles>COC(=O)C(C(C)=O)=C1CCSCC1CC=Cc1ccccc1</smiles>

$56 \%$ yield, $93 \%$ ee

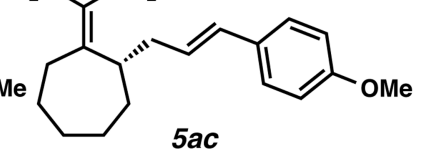

$72 \%$ yield, $96 \%$ ee $\mathrm{MeO}_{2} \mathrm{C} \smile \mathrm{CO}_{2} \mathrm{Me}$<smiles>CCCC[C@H]1CCCCCC1=C(C)CC=Cc1ccc(Br)cc1</smiles>
$95 \%$ yield, $97 \%$ ee<smiles>COC(=O)C(C(C)=O)=C1CCC[C@H]1CC=Cc1ccccc1</smiles>

$75 \%$ yield, $90 \%$ ee

Scheme 3. Substrate Scope of Sequential (One-Pot) Ir-Catalyzed Allylic Alkylation/Cope Rearrangement. ${ }^{a, b, c}$

${ }^{a}$ Reactions performed on a $0.2 \mathrm{mmol}$ scale in $2 \mathrm{~mL}$ of $\mathrm{THF}$ at $20^{\circ} \mathrm{C}$ for $12-16 \mathrm{~h}$, followed by stirring in toluene at $100{ }^{\circ} \mathrm{C}$ for $5 \mathrm{~h}$, see SI for details. ${ }^{b}$ Regioselectivity of the allylic alkylation determined by ${ }^{1} \mathrm{H}$ NMR analysis of the crude mixture ( $>20: 1 \mathrm{~b}: 1$ for all cases), and ee determined by SFC. ${ }^{c}$ Yields of isolated product. ${ }^{d}$ One-pot procedure employed. ${ }^{e}$ Inseparable mixture with carbonate $\mathbf{2 g}$, NMR yield. 


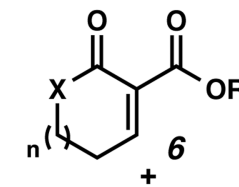

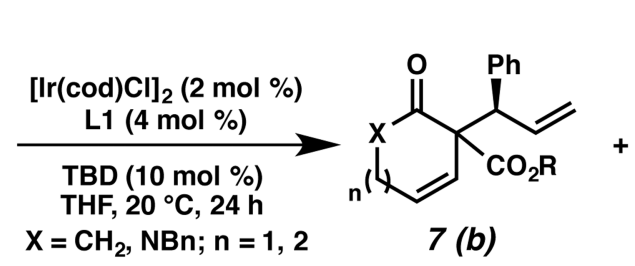

(⿻上丨

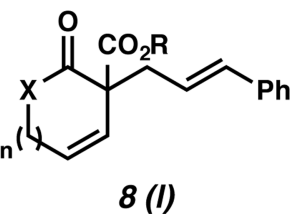<smiles>C=C[C@H](c1ccccc1)C1(OC(C)=O)C=CCCCC1=O</smiles>

$7 a a$

99\% yield, >20:1 b:I 2:1 dr, 95\% (88\%) ee<smiles>C=C[C@@H](c1ccc(C)cc1)C1(OC(C)=O)C=CCCCC1=O</smiles>

$7 a b$<smiles>C=CC(c1ccccc1)C1(C(OC)OC)C=CCCCCC1=O</smiles>

7 ba

$96 \%$ yield, $16: 1 \mathrm{~b}: \mathrm{I}$ 3:1 dr, $90 \%(77 \%)$ ee<smiles>C=C[C@H](c1cccc(OC)c1)C1(C(=O)OC)C=CCCCC1=O</smiles><smiles>C=C[C@H](c1ccccc1)C1(C(=O)OCC)C=CCCC1=O</smiles>

$7 c a$

$40 \%$ yield, $>20: 1 \mathrm{~b}: \mathrm{I} \quad 66 \%$ yield, $12: 1 \mathrm{~b}: \mathrm{I}$ $5: 1 \mathrm{dr}, 98 \%(90 \%)$ ee $2: 1 \mathrm{dr}, 79 \%(62 \%)$ ee<smiles>C=C[C@H](c1cccc(Cl)c1)C1(C(=O)OC)C=CCCCC1=O</smiles><smiles>C=C[C@H](c1ccccc1)C1(C(C)=O)C=CCCNC1=O</smiles>

$7 d a$<smiles>C=C[C@@H](c1ccc(Br)cc1)C1(OC(C)=O)C=CCCCC1=O</smiles>

$7 a f$

Scheme 4. Substrate Scope of Ir-Catalyzed Allylic Alkylation of Cyclic $\alpha, \beta$-unsaturated $\beta$ Ketoester. ${ }^{a, b, c, d}$

${ }^{a}$ Reactions performed with $0.4 \mathrm{mmol}$ of $6 \mathrm{a}$ and $0.2 \mathrm{mmol}$ of $2 \mathrm{a}$ in $2 \mathrm{~mL}$ of THF. ${ }^{b}$

Regioselectivity (b:1) was determined by ${ }^{1} \mathrm{H}$ NMR analysis of the crude mixture and ee was determined by SFC. ${ }^{c}$ Combined yields of isolated diastereomers. ${ }^{d}$ ee of the minor diastereomer given in parenthesis. 


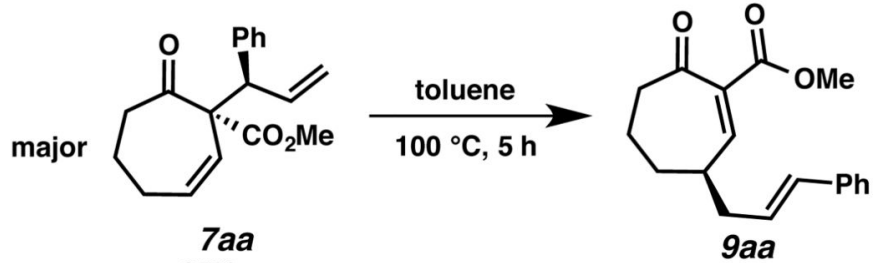

$95 \%$ ee

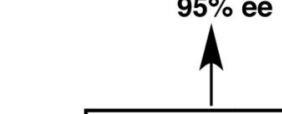

chromatographic separation

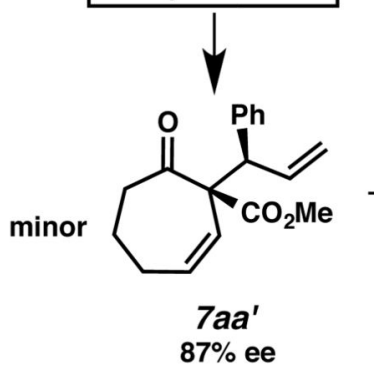

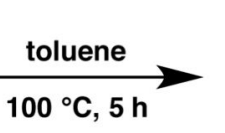

ent-9aa

$33 \%$ yield, $87 \%$ ee

$72 \%$ yield, $95 \%$ ee<smiles>COC(=O)C1=C[C@H](C/C=C/c2ccccc2)CCCC1=O</smiles>
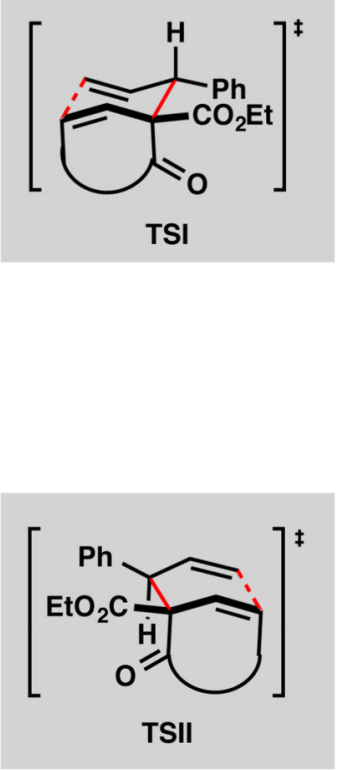

Scheme 5. Cope Rearrangement of Diastereomeric 1,5-Dienes 7

${ }^{a}$ Unreacted 7aa' was recovered in $61 \%$ yield and $86 \%$ ee. 


\section{를 \\ 골}

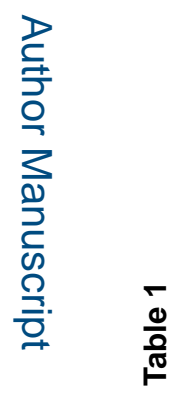

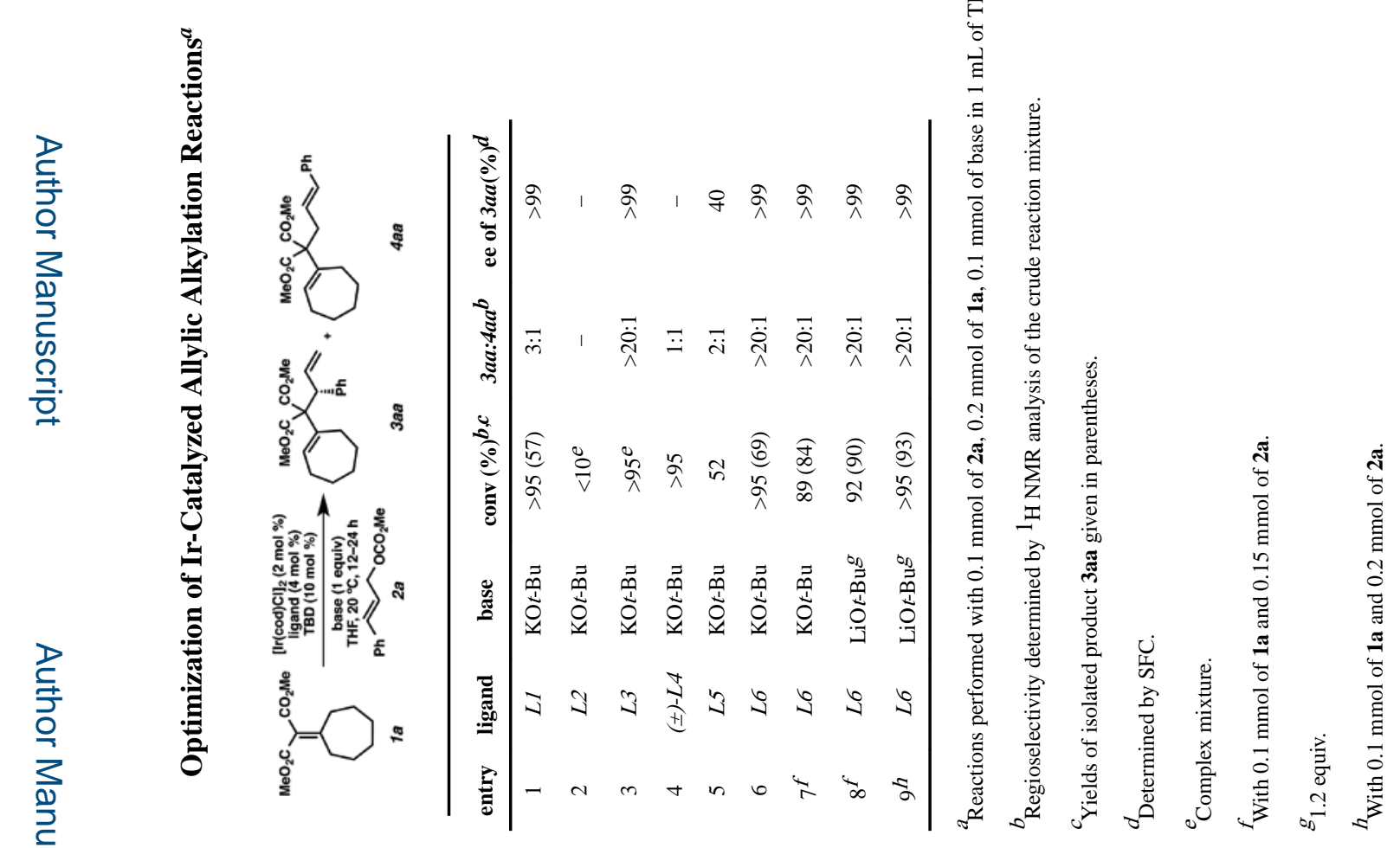

J Am Chem Soc. Author manuscript; available in PMC 2017 July 05. 


\section{룰}

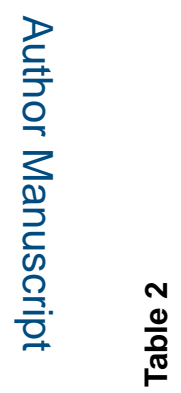

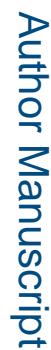

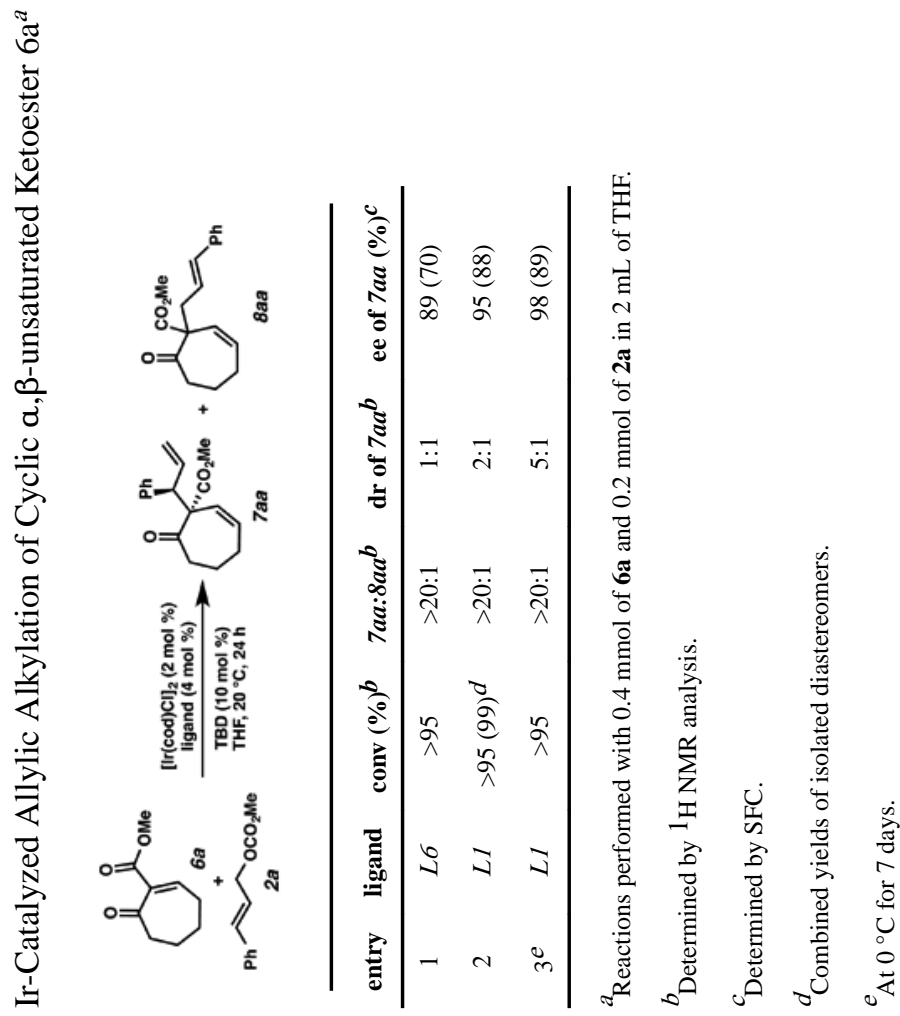

J Am Chem Soc. Author manuscript; available in PMC 2017 July 05. 